\title{
POLICY IMPLEMENTATION OF THE ENTERTAINMENT TAX COLLECTION (A Case Study at Local Revenue Office in Batu City)
}

\author{
Nila Kurnia Wati \\ Program of Public Administration, Faculty of Administration Science, Brawijaya \\ Andy Fefta Wijaya \\ Faculty of Administration Science, Brawijaya University \\ Choirul Saleh \\ Faculty of Administration Science, Brawijaya University
}

\begin{abstract}
ABSTRAK
Entertainment tax is one of the source of Local Revenue in Batu City along with the development of Batu City as tourism city. Therefore, Batu City government tries to optimize entertainment tax revenue by discharging the entertainment tax policy. The success or failure of this policy will be determined by the step of implementation. Unfortunately, policy implementation of entertainment taxes in Batu City still faces a problem, that is tax receivable problem. The aims of this research is to explain and analyse policy implementation of entertainment tax collection in Batu City through four important aspects in the policy implementation and analyse the factors exist in these policy implementation. This research uses qualitative method with case study approach. This research focused on (1) policy implementation of entertainment tax collection in Batu City, and (2) factors exist in the policy implementation of entertainment tax collection in Batu City. This research found that policy implementation of entertainment tax collection in Batu City has not been optimal. It's showed by the increasing of entertainment taxes that fluctuates and the lowest percentages of entertainment tax evenue on the Local Revenue in Batu City. Besides, there are four factors exist in this policy implementation there are communication, resources, disposition/attitudes, and beureaucratic structures. Unfortunatelly only communication factors that support this policy implementation.
\end{abstract}

Keywords: policy implementation, entertainment taxes

\section{INTRODUCTION}

Policy implementation is one of the important stages in the policy process. According to Noruzi and Irani (2011:2) "Policy implementation is the stage of policy making between the establishment of a policy and the consequences of the policy for the people whom effect. Also implementation involves translating the goals and objectives of a policy into an operating, ongoing program". This stage will determine the success or failure of policy, such as the explanation from Smith and Larimer (2009:157) that "The importance of implementation to policy success or policy failure is intuitively obvious". Therefore, it was needed to highlight in the policy process. 
Nila Kurnia Wati, Andy Fefta Wijaya, Choirul Saleh: Policy Implementation Of The Entertainment Tax

Collection 179

There were four aspects needed to highlight in the policy implementation such as explained by Anderson that the four aspects were who involved in the policy implementation, the nature of administration process, the compliance of a policy, and the effect of implmenetation (Tahir, 2011:89). The four aspects above would drive the policy implementation to achieve the goals that had been set.

Unfortunatelly, sometimes in the policy implementation there were several factors that will aid or hinder the success of policy implementation. According to Edwards III there were four factors would be affect policy implementation, that were communications, resources, disposition or attitudes and bureaucratic structures (Makinde, 2005:63 \& Tahir, 2011:96). The four factors operated simultaneously and they interacted with each other to aid or hindered policy implementation.

Entertainment tax was one of the sources of Local Revenue in Batu City, along with the development of this city as Tourism Destination. Therefore, Local Government in Batu City tried to optimize the entertainment tax revenue by issuing entertainment tax policy. The success or failure of this policy was determined by the implementation stage. Unfortunatelly, policy implementation of entertainment tax collection in Batu City still faced entertainment tax receivable problem. Entertainment tax became most types of overdue taxes in amount of 24 billion ... In particular entertainment tax receivables were overdue drastically in 2010-2013. In 2010, the entertainment tax arrears amounted to 350 millions. This number increased to 23 billions in 2011. This number continued to increase in 2012 to 23.4 billions and to 24.6 billions in 2013 (Cahya 2015).

The weak supervision carried out by council members also indicated being the main cause on crucial issues in the policy implementation of entertainment tax collection in Batu City. State Audit Agency reported as explained by Yustiningsih (2015) "Since 2010-2013 taxes always shortage in the big amount. It is caused by the weak supervision carried out by council members on the crucial issues in the related region to the supervision of the executive performance against the tax receivable In Batu City which still unsolved". It showed that the supervision of Local Parliament toward Batu City government performance looked weak because of the entertainment tax receivable in Batu City still unsolved.

The aims of this research was to explain and analyse policy implementation of entertainment tax collection in Batu City through four important aspects in the policy implementation according to Anderson and to describe and analyse the factors exist in these policy implementation of entertainment tax collection In Batu City based on the model of policy implementation from Edwards III. The significances of this research were to add the information for the authorities who wanted to study about public policy implementation of the local government entertainment tax collection in Batu City and could recommend for the government especially Local Revenue Officer's in the implementation of entertainment tax collection in Batu City. 
80| Ad'ministrare, Vol. 2 No. 2, Juli - Desember 2015

\section{LITERATURE REVIEW}

\section{Public Policy Implementation}

According to Smith and Larimer (2009:155) "From an implementation perspective, policy begins rather than ends with a formal declaration of what government is going to do ... The Declaration of intent the passage of a law has to somehow be translated into reality". Policy implementation referred to the actions that conducted to translate the policy. As asserted by Gasco (2004:329) that "Implement a policy means to take actions, to perform, to carry out programs". Therefore, policy implementation was carrying out of policy that made by policy makers through the actions conducted to translate the policy into reality.

\section{Policy Implementation Model}

One model of policy implementation was a model developed by George C. Edwards III in Tahir (2011:96) he argued that "In our approach to the study of policy implementation, we begin in the abstract and ask: what are the precondition for successful policy implementation? What are primary obstacles to successful policy implementation?" Therefore, the model was developed by George C. Edwards III that was looking at the pre-condition and main constraints that influence upon the success of public policy.

To know the pre-condition and main constraints that influence the success of public policy that Edwards III offers and consider four factors in implementing public policy as cited by Tahir (2011:96) and Makinde (2005:63) that the four factors were communication, resources, disposition or attitudes, and bureaucratic structure". Makinde (2005:63) stated, "The four factors operate simultaneously and they interact with each other to aid or hinder policy implementation". Therefore that factors would determine the successful or not of the policy implementation.

\section{Policy Implementation Aspects}

In achieving goals that had been set in the policy implementation, it needed to highlight the aspects of policy implementation. According to Anderson cited in Tahir (2011:89) policy implementation had four important aspects that were:

a. Actors involved in the Policy Implementation

The main actor that involved in the policy implementation was administrative agencies and practically they were supported by many other actors. According to Anderson (2010:233) "Although administrative agencies are the primary implementers of public policy, many other players may also be involved and contribute in various ways to the execution of policies". Therefore, in the policy implementation needed to highlight the actors who involved because there were many other players might also contribute.

b. The Nature of Administration Process 
Nila Kurnia Wati, Andy Fefta Wijaya, Choirul Saleh: Policy Implementation Of The Entertainment Tax

Collection $\mid 81$

Basically the policy only gave an agency the formal declaration to take action such as the explanation from Anderson (2010:243) "A statute only gives an agency the legal authority to take action to implement policy on some topic". To implement it needs both of procedures and concepts that would have been guided official behaviour. Anderson (2010:243) asserted that "The relevant laws, rules, and regulations, accepted modes of procedures, and concepts of fair play that help form and guide official behavior and to which officials expected to conform". Therefore, administrative process needed to highlight in the policy implementation both of procedures and concepts.

c. Compliance of Policy

The study of policy implementation needed to hightlight the compliance of policy. According to Anderson (2010:274) "A complete study of policymaking must cover not only the events leading up to a decision on policy but also what is done to implement it and, ultimately, whether people comply with it". Furthermore he explained that "Compliance with policy may also be based on some form reasoned, conscious acceptance. Even some whose immediate self interest conflicts with a policy may be convinced that it is reasonable, necessary, or just. Most people undoubtedly would rather not pay taxes, and many do try to avoid or evade their payment. But when people believe that tax laws are reasonable and just, or perhaps that taxation is necessary to provide needed governmental services, such beliefs will in all likelihood contribute to compliance with tax policy". Compliance with the policy would be driven by policy implementation to achieve the goals that had been set.

d. The Effect of Policy implementation

Policy implementation would give the intended or unintended effect. Intended effect would aid the success of policy implementation to reach the goals. While unintended effect wiould hinder it.

\section{Entertainment Tax}

In Batu City, the entertainment tax governed by the Batu City Regional Regulation No. 6 of 2010 about Entertainment Tax and the amendments in Batu City Regional Regulation No. 2 in 2012. Definition of entertainment tax based on Batu City Regional Regulation No. 6 of 2010 "Is the tax which levied on the entertainment business". Further in these regulation explained that the meaning of the entertainment businessman is "An individual or entity that organized an entertainment for and its own behalf or on behalf of another party dependents". This wass consistent with the definition of tax according to Priantara (2013: 542) that "Entertainment tax is a tax on entertainment business with paying of charge and does not include the entertainment business that is free of charge". Based on the understanding above could conclude that, entertainment tax was a contribution levied by local governments on an individual or entity that had entertainment business with paying of charge. 
82| Ad'ministrare, Vol. 2 No. 2, Juli - Desember 2015

\section{RESEARCH METHOD}

This research used qualitative method with case study approach. Qualitative method was chosen in this research because in the implementation of entertainment tax policy still had a problem and the researcher wanted to observe directly to the Local Revenue Office and several Entertainment Tax payers in Batu City relating with the implementation of entertainment tax collection policy. While case study approach was chosen because this research wanted to inquiry policy implementation of entertainment tax collection in Batu City through explores depth process of the implementation. Moreover, this research used data analysis technique from Creswell (2009:185).

\section{Collecting Data Methods}

The data was collected by observation, interview, and documentation. Observation was conducted to obtain a general pictures. The researcger visited Local Revenue Office in Batu City, so the data and information was needed can be fulfiled. The interview was conducted to several officers of Local Revenue Office, entertainment businessmen and visitors who enjoyed entertainment services in Batu City that related to the implementation of entertainment tax collection policy and several entertainment tax payers. While, in this research, the document that used is document or archive of Local Revenue Office in Batu City.

\section{RESULTS AND DISCUSSIONS}

\section{Policy Implementation of Entertainment Tax Collection in Batu City}

\section{Actors Involved in the Policy Implementation}

Actor was one of the important aspects in the policy implementation. Eventhough administrative agencies were the primary implementers of public policy, many other players might also be involved and contributed in various ways to the execution of policies (Anderson, 2014:233). Research findings showed that policy implementation of entertainment tax collection in Batu City involved three actors. They were Local Revenue Officers, entertainment businessmen, and visitors who enjoyed entertainment services.

Local Revenue Officers as the administrative agencies of Local Government in Batu City had the important role in providing public services relating with entertainment tax collection. Muluk explained, the role of local government was providing public services to the citizens that reflected from policy instruments (Muluk, 2009:114). Therefore, policy instruments of entertainment tax collection reflecting that, Local Revenue Office had the important roles in providing public services in the scope of administration process of entertainment tax collection and as the facilitators of this policy implementation through socialization, intensification and extension programs.

Moreover, research finding showed that, from policy instrument perspective, the character of Local Revenue Office in the policy implementation of entertainment tax collection 
Nila Kurnia Wati, Andy Fefta Wijaya, Choirul Saleh: Policy Implementation Of The Entertainment Tax

Collection $\mid 83$

was coercive. The entertainment businessmen were coerced by Local Revenue Officers in paying entertainment taxes, because this tax is the financial aspect of the Local Government in Batu City. Waluyo explained, tax was an important part in state revenue. When viewed from the state revenue, the state financial condition iwasnot only from revenues in the form of oil and gas, but rather seeks to make tax as the main revenue of stated (Waluyo, 2013:5). It showed that entertainment tax was one of the important source of the Local revenue in Batu City, because Batu City developed their City as tourism destination, so many entertainment business emerged to support this development. It reflected that entertainment taxes included to the budgetary function of taxes. Priantara explained that, budgetary function was a function located in public sector and tax was a tool or resource to enter as much money in to the state treasury that in time would be used to finance the state expenditures (Priantara, 2013:4). Therefore, entertainment tax was one of the sources of Local Revenue that had the function to finance the expenditure of Local Government in Batu City.

While the role of entertainment businessmen and visitors who enjoyed entertainment services were the target of entertainment tax policy. Research findings showed that entertainment businessmen were the object of entertainment taxes and the role of visitors who enjoyed entertainment services were the subject of taxes.

According to the type of taxes, entertainments tax could be grouping are as follows. According to the group of taxes, entertainment taxes included to the indirect taxes. Waluyo explained that, indirect taxes were taxes that the obligation could be delegated to others (Waluyo, 2013:12). Therefore, the imposition of entertainment taxes delegated to others that were visitors who enjoyed entertainment services. According to the nature of taxes, entertainment taxes include to the objective tax. Priantara explained that objective tax was a tax that time of the imposition of the first note is the object of the tax. Determining the subject was done after knowing the tax object. (Priantara, 2013:7). Therefore, according to the nature of taxes, the imposition time of entertainment taxes was based on the object of taxes. They were entertainment businessmen. After knowing that, the subject of taxes would be determined, they were visitors who enjoyed entertainment services. While, according to the collectors, entertainment taxes included to the Local Taxes. Waluyo explained that, local tax was a tax levied by local government and used to fund local households (Waluyo, 2013:12). Therefore, entertainment taxes were the tax that levied by Local Revenue Office as the administrative agency, and it would be used to fund households of Local Government in Batu City.

Based on the explanation above, it could conclude that the actors involved in the policy implementation was the important aspects in the entertainment tax collection in Batu City, because each of the actors had the different role. The attitudes of actors in the carrying out the role would support or constrain the policy implementation of entertainment tax collection in Batu City. Through the role of each actors could be concluded that policy implementation of entertainment tax collection could not run optimally. Although the role of administrative agencies supporting the implementation. Research finding showed that, policy implementation of entertainment tax collection was not only involved administrative agencies of Local Government, but also supported by several actors. There were three actors who involved in this policy implementation, namely Local Revenue Officers, entertainment businessmen, and 
84| Ad'ministrare, Vol. 2 No. 2, Juli - Desember 2015

visitors who enjoyed entertainment services. The role of Local revenue Officers was as the administrative agencies that would facilitate this policy implementation through socialization, intensification, extension programs and carrying out administration process of entertainment tax collection, while entertainment businessmen, and visitors who enjoyed entertainment services were the target of entertainment tax policy.

\section{Administration Process of the Entertainment Tax Collection in Batu City.}

Entertainment tax policy only gave the formal declaration to take action on the entertainment business that had emerged in Batu City. Anderson explained that, a statute only gaves an agency the legal authority to take action to implement policy on some topic (Anderson, 2014:243). It showed that entertainment tax policy was one of the regulation issued along with the development of Batu City as a Tourism City, so many entertainment business had emerged. Entertainment taxes were expected could give contribution to the Local Revenue in Batu City. Tp apply the implementation, it needed both of procedures and concepts that guided official behaviour. Anderson (2014:243) asserted "The relevant laws, rules, and regulations, accepted modes of procedures, and concepts of fair play that help form and guide official behaviour and to which officials expected to conform". Therefore, administrative process needed to highlight in policy implementation of entertainment tax collection in Batu City. There were 6 (six) procedures in the administration process of entertainment tax collection in Batu City, that are registration, data collection, depositing, accounting and reporting, assessment, and billing procedures.

In Batu City, the procedures of entertainment tax collection carried out based on the self-assessment system. Gunadi explained that, in the self-assessment system, taxpayer should calculate, pay or deposit and report of taxes, while the tasks of tax apparatus should carry out services, monitore and found the implementation of the duty of taxes that implemented by taxpayers (Gunadi, 2005: 16). Research findings showed that entertainment taxpayers calculate, paying or depositing and reporting of their taxes, while Local Revenue Officers as tax apparatus of entertainment tax carrying out service, monitoring and founding the tax collection. Entertainment taxpayers should go to Local Revenue Office and register their business as the Object of entertainment tax. If they had obtained NPWPD, they could fulfil data collecting form, and they could deposit their taxes after Local Revenue Office issued SPTPD, while Local Revenue Office as the providers of tax services.

Unfortunately, in the administration process, taxpayers still didn't comply with the requirements of self assessment system. Gunadi explained that, one of the requirements of self assessment system was the awareness of taxpayers in paying taxes (Gunadi, 2005:19), but research findings showed that several entertainment businessmen in Batu City still didn't have the awareness to pay entertainment tax. Moreover, they gave improper report of their tax. Whereas this system gave, the reliance for entertainment businessmen to calculate, pay or deposit and report their taxes. Therefore, administration processes of entertainment tax collection in Batu City was not suitable with self assessment system. 
Nila Kurnia Wati, Andy Fefta Wijaya, Choirul Saleh: Policy Implementation Of The Entertainment Tax

Collection $\mid 85$

\section{Compliances in the Policy Implementation}

In the study of policy implementation, especially entertainment tax collection needed to highlight the compliance of policy. Anderson explained that, a complete study of policy making must cover not only the events leading up to a decision on policy, but also what had done to implement it and, ultimately, whether people comply with it (Anderson, 2014:274). Therefore, in the study of policy implementation of entertainment tax collection needed to highlight the compliance of peoples with it of both implementers and the targets of policy.

Tahir explained the compliance of policy implementers was one of the important aspects in the policy implementation, due it would be reflecting the effectiveness of policy (Tahir, 2011:89). Research findings showed that the compliance of policy implementers had not been optimal. Based on the tax collection principles, the compliance of policy implementer in policy implementation had been suitable with certainty, convenience and economic principles. Adam Smith explained that, the tax which each individual is bound to pay ought to be certain and not arbitrary. The time of payment, the manner of payment, the quantity to be paid, ought all to be clear and plain to the contributor and to every other person (Hancock, 1851:8). Research findings showed that the compliance of implementer had been suitable with certainty, convenience and economic principles. Implementers did not collect entertainment tax to the taxpayers with arbitrary decisions, but carrying out properly with the amount of taxes that was calculated by taxpayers based on the rates that assessed in the Batu City Regional Regulation No.2 of 2012. Besides, time and the due date of entertainment taxes had been determined clearly that was after more that the due date (after the 10th of each month).

In the policy implementation of entertainment tax collection, the compliance of implementers also had been suitable with convenience principle. Adam Smith explained that, every tax ought to be levied at the time or in the manner in which it is most likely to be convenient for the contributor to pay it (Hancock, 1851:8). Research findings showed that entertainment taxes levied in the time that did not complicated the taxpayers that were every months.

In the policy implementation of entertainment tax collection, the compliance of implementers also had been suitable with economic principle. Adam Smith explained that, every tax ought to be so contrived as both to take out and to keep out of the pockets of the people as little as possible over and above what it brings into the public treasury of the state (Hancock, 1851:8). Research findings showed that the charge that imposed to the taxpayers lower than previous years. It showed that in the changing of entertainment tax rates based on Batu City Regional Regulation No. 2 in 2012.

Practically, in the policy implementation of entertainment tax collection, the compliance of policy implementer had not been suitable to equality principle yet. Adam Smith explained that, the subjects of every state ought to contribute towards the support of the government as nearly as possible in proportion to their respective abilities; that is, in proportion to the revenue which they respectively enjoy under the protection of the state (Hancock, 1851:8). Based on this principle, entertainment tax collection should carry out equals to all of the entertainment businessmen in Batu City. Unfortunately, until now there were still many entertainment 
businessmen that didn't paying their taxes such as spa business. It showed that the compliance of policy implementers had not been optimal yet.

While the compliance of taxpayers in paying taxes had not been optimal yet. Several entertainment businessmen still did not pay tax and entertainment tax revenue that had been increased fluctuates and tax receivable that had unsolved showed that the compliance of entertainment taxpayers had not been optimal yet. Therefore, even the government had been carried out several efforts in increasing the awareness of entertainment taxpayers in paying taxes, but practically several entertainment businessmen still avoid in paying taxes.

Research findings showed that the awareness and the compliance of taxpayers in paying entertainment taxes were affected by several factors. This was suitable with the opinion from Burton that there were four factors that affecting the compliance of taxpayers namely, tax rates, the implementation of billing taxes that orderly and consistent; the punishment and the implementation of punishment that consistent and equally (Burton, 2005:4-6). Research finding showed that based on the tax rates, the awareness of entertainment taxpayers and the entertainment revenue was increasing since Batu City Government change the basic imposition rates of entertainment taxes in the Batu City Regional Regulation No. 2 in 2012. The previous regulations assessed the basic rates of entertainment tax higher with this regulation. Therefore, it showed that basic rates affected the compliance of taxpayers in paying taxes.

Based on the implementation of billing taxes, research finding showed that this implementation had not been consistent. It showed on the several entertainment business that still did not pay their taxes, such as spa business, moreover in Batu City still emerge entertainment tax receivable problem. Therefore, it showed the consistent implementation of billing field would affect the compliance of taxpayers in paying taxes.

Based on the punishment, research findings showed that it clearly explained in the Article 15 point 6 of Batu City Regional Regulation No. 6 in 2012 about entertainment taxes. This regulation clearly explained that taxpayers would accept punishment if they didn't paying taxes before the due date. Taxpayers should pay interest $2 \%$ for each month, if they payed taxes more than the due date. But unfortunately, research findings showed that this punishment still didn't affect the compliance of taxpayers in paying taxes. It showed on the entertainment tax receivable that had unsolved.

Based on the implementation of punishment research finding showed that the punishment was not consistent. The implementation of punishment in the entertainment tax collection suitable with Batu City Regional Regulation No. 6 in 2012 about entertainment taxes but didn't implement properly. The entertainment tax receivable problem that had unsolved showed that the implementation of punishment didn't implemented consistency.

Based on the analysis above could conclude, the compliance of entertainment taxpayers in Batu City had not been optimal. The main cause of this problem is the implementation of billing taxes that still not consistent. Therefore, several entertainment businessman still did not register their taxes, and tax receivable problem that had unsolved. 
Nila Kurnia Wati, Andy Fefta Wijaya, Choirul Saleh: Policy Implementation Of The Entertainment Tax

Collection $\mid 87$

\section{The Effect of Policy Implementation}

Policy implementation would give the intended or unintended effect. Therefore, the effect of policy implementation was one of the important aspects needed to hightlight in the policy implementation of entertainment tax collection in Batu City. According to Gasco, implementing a policy meant to take actions, to perform, to carry out programs (Gasco, 2004:329). Policy implementation of entertainment tax collection was the action taking by Local Revenue Office in Batu City, through socialization, intensification, extension of entertainment tax collection and administration process of entertainment tax collection to achieve policy goal that was increasing entertainment tax revenue so it could give contribution in increasing Local Revenue in Batu City. Therefore, the effect of policy implementation of the entertainment tax collection could be seen through entertainment tax revenue and these contributions to the Local revenue in Batu City.

In the last four years, research findings showed that policy implementation of entertainment tax collection had given the effect in increasing entertainment tax collection in Batu City, it was showed in Table. 1.

Table 1. Realization of Entertainment Tax Revenue in Batu City in 2007-2014

\begin{tabular}{rrr}
\hline No & Years & Realization (IDR) \\
\hline 1 & 2007 & $1,490,996,971$ \\
2 & 2008 & $1,371,712,570$ \\
3 & 2009 & $1,978,360,490$ \\
4 & 2010 & $2,766,190,750$ \\
5 & 2011 & $3,751,062,526$ \\
6 & 2012 & $3,402,281,809$ \\
7 & 2013 & $6,296,771,461$ \\
8 & 2014 & $6,019,223,859$ \\
\hline
\end{tabular}

Source: Secondary Data from Local Revenue Office in Batu City in 2015

Table 1 above showed that the realization of entertainment tax revenue was increasing fluctuates. In 2009, 2010, 2011, and 2013 entertainment tax was increasing from the previous years, while in the 2008, 2012, and 2014 entertainment tax decreased. The higher realization was achieved in 2013, while the lowest realization achieved in 2008. Table 1 above also showed that in the several years (in the 2008, 2009, and 2010) entertainment tax revenue could not achieve the target that had been set. Pressman and Wildavsky explained that, policy implementation might be viewed as a process of interaction between the setting of goals and actions geared to achieve them (Paudel, 2009:36). Therefore, policy implementation of entertainment tax collection in Batu City could viewed as a process that carrying out to achieve the goal in increasing entertainment tax revenue through administration processes of entertainment tax collection.

Entertainment tax revenue in several years had been increased fluctuates because the effect of policy implementation of entertainment tax collection that had not been optimal. 
O'Toole explained that, policy implementation refers to the connection between the expression of governmental intention and actual result (Paudel, 2009:37). Research findings showed that even if Batu City Government had carried out programs that supported entertainment tax collection, such as socialization, intensification, extension of tax collection and carried out administration process, but the result of these programs had not been optimal.

This study tried to understand policy implementation of entertainment tax collection through administration perspectives. Djaja Saefullah explained that, the administrative perspective that matters of public policy was associated with the system, procedures, and mechanism, as well as the ability of official officers in interpreting and implementing public policy, so that the desired vision and expectations could be met in reality (Tahir, 2011:83). Unfortunately, as one of the source of Local revenue in Batu City, entertainment tax revenue still did not give the significance contribution in increasing Local Revenue. Research findings showed that in the last several years entertainment tax revenue had been increased fluctuates in increasing Local Revenue.

Tabel 2. The Percentages of Entertainment Tax Revenue on The Local Revenue in Batu City in 2007-2014

\begin{tabular}{clr}
\hline No & Years & Percentages $(\boldsymbol{\%})$ \\
\hline 1 & 2007 & 9.12 \\
2 & 2008 & 9.66 \\
3 & 2009 & 11.38 \\
4 & 2010 & 15.6 \\
5 & 2011 & 12.4 \\
6 & 2012 & 8.77 \\
7 & 2013 & 10.55 \\
8 & 2014 & 7.69 \\
\hline
\end{tabular}

Source: Secondary Data from Local Revenue Office in Batu City in 2015

Table 2 above showed that in the last eight years, the percentages of entertainment tax revenue on the Local Revenue in Batu City increase fluctuates. It showed that, policy implementation of entertainment tax had been given the effect in increasing Local Revenue in Batu City but still had not been optimal.

\section{Factors Exist in the Policy Implementation of Entertainment Tax Collection in Batu City}

\section{Communication Factor}

Communication factor had an important role as guidance for the policy implementer of entertainment tax. Edwards III explained that communication was an essential ingredient for effective implementation of public policy (Makinde, 2005:63). In the policy implementation of entertainment tax collection, communication was an essential ingredient for effective implementation, so the goals of this policy would be achieved. Research finding showed that 
Nila Kurnia Wati, Andy Fefta Wijaya, Choirul Saleh: Policy Implementation Of The Entertainment Tax

Collection $\mid 89$

there were two important aspects exist in the policy implementation of entertainment tax collection. They were policy transmission and policy clarity.

Edwards III explained that implementation instructions that were not transmitted, that distorted in transmission, that were vague, or that were inconsistent might cause serious obstacles to policy implementation (Makinde, 2005:63). Research found that Local Revenue Officers transmit entertainment tax policy into the socialization, intensification and extension of entertainment tax collection. It showed that policy implementation instructions of entertainment tax collection in Batu City had been taransmited to the several programs of entertainment tax collection and it would be supported the policy implementation of entertainment tax collection in Batu City.

Tahir explained that any goals and targets of the policy should be socialized to the target groups that would reduce the distortion of implementation (Tahir, 2011:97). Research finding showed that entertainment tax policy in Batu City had socialized to the entertainment businessment as the target groups. Socialization carried out as an effort to give adequate information to the entertainment businessmen, in order they in compliance with entertainment tax policy. The socialization wasgivn more the awareness of entertanment taxpayers in paying taxes, but unfortunately it still didn't reduce the distortion of policy implementation of entertainment tax collection such as the emergence of entertainment tax receivable that still unsolved.

Soemitro explained that extension carried out as an effort in increasing entertainment tax revenue, it could be conducted through finding the new object of taxes, and extends the scope of taxes (Maulana, 2012:7). In the entertainment tax collection in Batu City, Local Revenue Officers found the new object of taxes through directly goes to fieldwork, and to extend the scope of entertainment taxes, it carried out through collecting data of new object of entertainment taxes. Based on the research finding, it showed that intensification and extension of entertainment tax collection had been increasing the awareness of entertainment taxpayers in paying their taxes.

Moreover Edwards III explained that inadequate information could lead to a misunderstanding on the part of the implementers who might be confused as to what exactly were required of them (Makinde, 2005:63). In the policy implementation of entertainment tax collection needed adequate information so the implementers knew the action took and the target of policy in compliance with this policy. Moreover, through policy clarity, the massages in the entertainment tax policy would be easier to translate into the programs. Through policy clarity orders to implement entertainment tax collection transmitted to the appropriate personnel that are Local Revenue Officers in Batu City. The perfection of policy implementation of entertainment tax collection, could be achieved if the implementation instruction and the clarity of massages in the policy acceptable clearly, because it would give impact to the implementers when implemented a policy. If the messages in the policy unacceptable clearly, so the different interpretation might be occurs. Therefore, policy clearly was one of the important aspects in the communication, because it would support policy implementation of entertainment tax collection. 
Based on the explanation above could be concluded that communication is the supporting factors in the policy implementation of entertainment tax collection in Batu City. Factor communication were exists consisted of policy transmission and policy clarity. Policy transmission was supported policy implementation of entertainment tax collection through socialization, intensification and extension of entertainment tax collection. While policy clarity was supported policy implementation of entertainment tax collection through adequate information that explained clearly into regional regulations.

2. Resources Factor

Resource was one of the important factors in the policy implementation. Tahir explained that resources in the form of human resources and financial resources influence the successful implementation of the policy (Tahir. 2011:97). Resources factor that exist in the policy implementation of entertainment tax collection are human resources, finances, and facilities.

Human resource was one of the important aspects in the resources factor. Grindle explained that resources in an organization include the capacity of organization and the people who involved in it (Tahir, 2011:104). Research finding showed that in Local Revenue Office, human resources still inadequate yet. In several important section sizes of human resources still less, whereas, human resources was the important factor in the policy implementation. Capacities of Local revenue Office as an implementer of entertainment tax policy still less. Tahir explained that the important sources in the policy implementation included the staff that must have the skills and the ability to carry out the task (Tahir, 2011:115). Practically, there were still lacks of human resources that have background of study in taxes. It showed that the skill of Local Revenue Officers who handled entertainment tax collection still less. Whereas, the skill that owned by Local Revenue Officers would support the implementation of tasks. Therefore, policy implementation of entertainment tax collection had not been optimal yet.

The availability of budget was one of the important aspects in the resources factor. Makinde explained that without sufficient resources, it meant that laws would not enforce, services did not provide and reasonable regulations did not develop (Makinde, 2005:64). Research finding showed that the availability of budget in the Local Revenue Office still inadequate. Local Revenue Officers tried to optimize the using of the limited of budget to finance the programs of tax collections. It meant that entertainment tax policy enforced but had not been optimal yet. Moreover, research findings showed that, although there were the limitedness of budget, services of entertainment tax collection still provided, it showed by the processes administration of entertainment tax collection that carried out through several procedures. They were registering, data collecting, depositing, accounting and reporting, assessing and billing of entertainment taxes. Unfortunately, this process was unsuitable with self-assessment system. Although the regulation developed in the socialization programs but it had not been optimal because the inadequate of financial.

Besides, facilites was one of the important aspects in the resorces factor. Makinde explained that facilities such as land, equipment, buildings, etc. as might be deemed as necessary for the successful implementation of the policy (Makinde, 2005:64). Research finding showed that the availability of facilities in the Local Revenue Office had been sufficient. 
Nila Kurnia Wati, Andy Fefta Wijaya, Choirul Saleh: Policy Implementation Of The Entertainment Tax Collection $\mid 91$

Through the sufficient of facilities, so the programs of entertainment tax collection would run effectively and optimally. Unfortunately it has not occured yet, because another resources did not support. Therefore, policy implementation of entertainment tax collection in Batu City had not been optimal.

Based on the explanation above, it could be concluded that the availability of resources in the policy implementation of entertainment tax collection in Batu City was important but it was still inadequate, mainly in human resources and budget. Although the facilities supported policy implementation of entertainment tax collection, this policy had not been implemented optimally because it did not supported by sufficient human resources and budget. Therefore, resources factor still became constraining factors in the policy implementation of entertainment tax collection in Batu City.

4. Bureaucratic Structure

Bureaucratic structure was one of the important factors in the policy implementation of entertainment tax collection in Batu City. Makinde explained, it was being the concern that communication, resources, and positive disposition were put in place did not guarantee the successness of the implementation. If there was no efficient bureaucratic structure, the problem of implementation could still arise especially when dealing with complex policies (Makinde, 2005:64). Therefore, even policy implementation had good communication, resources, and positive disposition/attitudes, it did not guarantee that policy implementation will be success if bureaucratic structures did not support it.

Coordination was one of the important aspects in the policy implementation of entertainment tax collection in Batu City. Research findings showed that Local Revenue Office in Batu City fragmented into several parts. Therefore, to carry out of the tasks perfectly, it needed proper coordination, because sometimes bureaucratic fragmentation would inhibits the implementation of the policy. Tahir explained that, the origin of the organizational characteristic and different bureaucratic fragmentation would inhibits the implementation of the policy. They always inhibit the implementation of policies, waste of resources, cause the unexpected action, and inhibiting coordination (Tahir, 2011:109). If the coordination did not carry out properly, it would inhibits policy implementation. Research findings showed that the coordination between units in the Local Revenue Office were manually. They still did not have the sophisticated application that coul be used to deliver the information between units, so the reporting of the data between unit carrying out manually. Therefore, coordination was one of the constraining factors in the policy implementation of entertainment tax collection in Batu City.

Standard operating procedure was one of the important aspects in the policy implementation of entertainment tax collection in Batu City. It had become a standard guideline for each implementer in the act. Tahir explained, as a policy administrator, organizational units established a standard operation procedure for handling routine tasks as the normally handle. Unfortunately, the standard designed to policies that had been run and less able to thw function properly for new policies, so it was difficult to change, delay, renewal, or actions that did not desire. Sometimes standards inhibit more than assisting in policy implementation. However the implementers might be know what should they do and had the desire and resources to carry out the policy, but inappropriate bureaucratic structure would be an obstacle to achieve the 
$92 \mid$ Ad'ministrare, Vol. 2 No. 2, Juli - Desember 2015

successful of policy (Tahir, 2011:109). Research findings showed that Local Revenue Office still didn't have SOP about entertainment tax collection, whereas SOP was one of the important aspect of the policy implementation of entertainment tax collection. According to Tahir, sometimes standards inhibited more than asissted in policy implementation of entertainment tax collection, through clear standards policy implementers would be known what they should do because it would handle routine tasks. Therefore, the lacks of SOP that became the clear standard of entertainment tax collection was one of the constraining factors in the policy implementation of entertainment tax collection.

Based on the explanation above, research findings showed that there were four factors were exist in the policy implementation of entertainment tax collection in Batu City, namely communication, resources, disposition/attitudes and bureaucratic structures. Makinde explained that, the four factors operated simultaneously and they interact with each other to aid or hinder policy implementation (Makinde, 2005:63). However, research findings showed that not all of these factors supported the implementation of this policy but several factors were being constraining factors.

\section{CONCLUSIONS}

Based on the research findings and discussion on the previous chapter, so it could concluded were as follows:

1. Research findings showed that policy implementation of entertainment tax collection in Batu City had not been optimal. It reflected of both entertainment tax revenue that increased fluctuates and the low contribution percentage of entertainment tax revenue on the Local Revenue in Batu City. Moreover, research discussions show that policy implementation of entertainment tax collection was not suitable with self-assessment system principles. It was reflected of both, several entertainment businessmen did not report their taxes properly, and the lack awareness of several entertainment businessmen in paying tax.

2. Research findings showed that there were four factors exist in the policy implementation of entertainment tax collection in Batu City, namely communication, resources, disposition or attitudes and bureaucratic structures. Nevertheless, several factors became constraining factors in the implementation of this policy. Supporting factor is communication, while Resources, disposition/attitudes and bureaucratic structur still being constraining factors.

\section{REFERENCE}

Anderson, James E. 2010. Public Policy Making. USA: Wadsworth Cengage Learning.

Cahya, Akmal Adi. 2015. Entitas Kebal Pajak: Pemerintah Penakut, Rakyat Sengkarut. Malang Corruption Watch. [Internet] 2 February. Available from <http://mcw malang.org/publikasi/entitas-kebal-pajak-pemerintah-penakut-rakyat-sengkarut>. [Accessed: February 13, 2015]. 
Nila Kurnia Wati, Andy Fefta Wijaya, Choirul Saleh: Policy Implementation Of The Entertainment Tax

Collection $\mid 93$

Creswell, John W. 2009. Research Design: Qualitative, Quantitative, and Mixed Methods Approaches. $3^{\text {rd }}$ Editions. USA: SAGE Publications, Inc.

Gasco, Mila. 2004. Policy Implementation. In: David Schultz. Encyclopedia of Public Administration \& Public Policy. New York: Facts On File, Inc.

Gunadi M., Djoned (2005) Administrasi Pajak. Jakarta: Lembaga Pengkajian Keuangan Publik dan Akuntansi Pemerintah Badan Pendidikan dan Pelatihan Keuangan Departemen Keuangan RI.

Hancock, W. Neilson. 1851. On the General Principles of Taxation as Illustrating the Advantages of a Perfect Income Tax. Paper: Dublin Statistical Society.

Makinde, Taiwo. 2005. Problems of Policy Implementation in Developing $\quad$ Nations: The Nigerian Experience. Vol. 11 (1), p. 63-69.

Maulana, Akhmad Hanafi. 2012. Intensifikasi dan Ekstensifikasi Pajak Hiburan Guna Meningkatkan Pendapatan Asli Daerah Koa Malang: Studi Kasus pada Pendapatan Daerah

Muluk, Khairul. 2009. Peta Konsep Desentralisasi dan Pemerintahan Daerah. Surabaya: ITS Press.

Noruzi, Mohammad Reza dan Irani, Farhad Nezad Haj Ali. 2011. Policy Affairs and Policy Implementation Issues; How Policy Implementation Can Be Effective?. Vol. 1 (1) June, hlm. 1-6.

Paudel, Narendra Raj. 2009. A Critical Account of Policy Implementation Theories: Status and Recondision. Vol. xxv (2), December. p.36-54.

Priantara, Diaz. 2013. Perpajakan Indonesia. ${ }^{2 n d}$ Edition. Jakarta, Mitra Wacana Media.

Smith, Kevin B., dan Larimer, Christopher W. 2009. The Public Policy Theory Primer. USA: Westview Press.

Tahir, Arifin. 2011. Kebijakan Publik dan Transparansi Penyelenggaraan Pemerintahan Daerah. Jakarta: PT. Pustaka Indonesia Press.

Waluyo. 2013. Perpajakan Indonesia. $11^{\text {th }}$ Edition. Jakarta, Salemba Empat.

Yustiningsih, Rini. 2015. Piutang Pajak Kota Batu Capai RP.22 Miliar. Solopos [Internet], 3January. Available from <http://www.solopos.com/2015/01/03/piutang-pajak-kotabatu-capai-rp22-miliar 564718?mobile_switch=mobile> [Accessed: February 13, 2015]. 